\title{
Sonication of antibiotic-loaded cement spacers in a two-stage revision protocol for infected joint arthroplasty
}

Massimo Mariconda ${ }^{1 *}$, Tiziana Ascione ${ }^{2}$, Giovanni Balato ${ }^{1}$, Renato Rotondo ${ }^{3}$, Francesco Smeraglia ${ }^{1}$, Giovan Giuseppe Costa ${ }^{1}$ and Marco Conte ${ }^{4}$

\begin{abstract}
Background: Culturing of the sonication fluid of removed implants has proven to be more sensitive than conventional periprosthetic tissue culture for the microbiological diagnosis of prosthetic joint infection. Since bacteria surviving on antibiotic-loaded cement spacers used in a two-stage exchange protocol for infected arthroplasties may cause the persistence of infection, in this study we asked whether the sonication also could be used to identify bacteria on antibiotic-loaded cement spacers removed at the second surgical stage during a twostage exchange procedure to confirm whether or not the prosthetic joint infection had been eradicated.

Methods: We cultured the sonication fluid of cement spacers that had been originally implanted in a two-stage exchange protocol in 21 patients (mean age, 66 years) affected by prosthetic joint infection (16 total knee prostheses and 5 hip prostheses). The cement spacers were vortexed for 30 seconds and then subjected to sonication (frequency $35-40 \mathrm{KHz}$ ). The resulting sonicate fluid was cultured for aerobic and anaerobic bacteria.

Results: The sonication fluid culture of the removed spacer was positive in six patients (29\%), with isolation of methicillin-sensible Staphylococcus Aureus (MSSA) in three cases, methicillin-resistant Staphylococcus Aureus (MRSA) in one case and Pseudomonas Aeruginosa in two cases. In three of these positive cases, the traditional culture of periprosthetic tissue was negative. Two patients with positive sonication culture of the spacer were successfully treated by early debridement of the revision prosthesis and systemic antibiotic therapy. In three patients a knee arthrodesis was planned and performed as the second surgical stage. In two of them the infection was caused by highly resistant Pseudomonas Aeruginosa. The other patient with a MSSA infection had been poorly compliant with the systemic antibiotic therapy due to her mental impairment. The patient originally affected by MRSA infection of his primary hip arthroplasty developed recurrent infection of his revision prosthesis and eventually underwent Girdlestone arthroplasty.
\end{abstract}

Conclusions: The sonication culture can be used to discover any bacteria on the antibiotic-loaded cement spacer during a two-stage exchange protocol, thus permitting the adoption of timely treatment options, such as the early prosthetic debridment.

Keywords: Prosthesis-related infections, Sonication, Bone cements, Treatment outcome, Microbial biofilm

\footnotetext{
* Correspondence: maricond@unina.it

${ }^{1}$ Department of Orthopaedic Surgery, "Federico II" University, Policlinico

Federico II, Via S. Pansini 5, bd. 12,80128, Naples, Italy

Full list of author information is available at the end of the article
} 


\section{Background}

A two-stage exchange procedure is commonly used for treating a prosthetic joint infection (PJI). It entails removal of the prosthesis with debridement of all infected tissue followed by administration of antimicrobial therapy, and subsequent delayed reimplantation of a second prosthesis. The temporary implantation of an antibioticloaded cement spacer facilitates the ease and safeness of the revision because it permits us to preserve the joint space during the interim period and ensures local release of antibiotics. High rates of satisfactory outcomes in terms of infection eradication have been reported using the two-stage exchange procedure [1], but in some cases both the clinical picture and serum C-reactive protein (CRP) levels do not normalize over time even with the removal of the infected implant and the prolonged implantation of the antibiotic-loaded cement spacer [2]. In these cases, the presence of biofilm-forming pathogens may cause the infection to persist and the antibioticloaded cement itself can act as a biomaterial surface to which bacteria may preferentially adhere, grow and possibly even develop antibiotic resistance [3]. Ultrasound treatment may be used to dislodge biofilm bacteria from the surface of orthopaedic implants allowing significant recovery of microorganisms [4]. Culturing of the sonication fluid has proven to be more sensitive than conventional periprosthetic tissue culture for the microbiological diagnosis of PJI $[5,6]$. In this study we asked whether the sonication also could be used to identify bacteria on antibiotic-loaded cement spacers removed at the second surgical stage during a two-stage exchange procedure, a) to confirm whether or not the PJI had been eradicated and $b)$ to compare the findings from conventional intraoperative tissue cultures with the findings after sonication of the cement spacer.

\section{Methods}

From March 2009 to January 2011 we performed a twostage exchange procedure in 21 consecutive patients, 10 women and 11 men, affected by PJI (16 total knee prostheses and 5 hip prostheses). Mean patient age was 66.1 years (range, 55-78 years). The diagnosis of suspected prosthetic infection was made on the basis of clinical signs and symptoms (reported pain, hyperthermia, swelling, redness), preoperative microbiological cultures (material from joint aspiration or sinus track), laboratory studies (leukocytosis, increased CRP), plain radiographs, and nuclear medicine findings ( $99 \mathrm{~m}$-Tc HMPAO labeled leukocyte scan or 18-fluorodeoxyglucose positron emission tomography (FDG-PET) scan). To be included in this study, that was approved by the institutional review board of the Department of Surgery and Orthopaedics of Federico II University, Naples, Italy and is compliant with the Helsinki Declaration, all individuals gave their oral and written informed consent for the publication of individual clinical details. They met at least one of the following criteria to confirm the infection [7]: i) two or more cultures of joint aspirates or cultures of intraoperative specimens yielding the same microorganism; ii) purulence surrounding the prosthesis at the time of explantation; iii) acute inflammation consistent with infection during pathohistological examination; iv) a sinus tract that communicated with the prosthesis. Removal of the prosthesis with debridement of all infected tissue and placement of a temporary molded antibiotic-loaded cement spacer was performed in each case. All these spacers contained gentamicin plus clindamycin, but in three cases an extra $2 \mathrm{~g}$ vancomycin was added. At the time of the first surgical stage, five specimens of periprosthetic tissue were intraoperatively collected under sterile conditions and sent for microbiological and histopathological diagnosis. The prosthetic components were packed into sterile containers, covered with four-hundred millilitres of Ringer's solution, and sent for sonication fluid analysis. The resection of prosthetic components was followed by intravenously administered empirical antibiotic treatment for one week until the cultures and susceptibility tests were available. Combination therapy including drugs showing activity against biofilms was used on an outpatient basis thereafter, according to the sensitivity profile of the cultured microorganisms. In 3 patients (14.3\%) with negative pre- and intra-operative cultures and positive histology showing acute inflammation consistent with infection, an empirical combination antibiotic treatment including rifampin was given. The second surgical stage was performed after clinical and laboratory findings had normalized. Antibiotic therapy was discontinued at least two weeks before surgery. The time interval between the removal of the infected prosthesis and the reimplantation of the second prosthesis varied, depending on the clinical and laboratory response to antibiotics and the cultured microorganism (Table 1). At the time of the cement spacer removal, multiple specimens of periprosthetic tissue were collected and sent for microbiological and histopathological studies. The cement spacers were packed into sterile containers, covered with four hundred millilitres of Ringer's solution, and sent for sonication. After the hospital discharge, patients were checked clinically, serologically, and radiographically at 2, 4, 12, and 24 weeks after the second surgery. Thereafter, clinical, serologic (CRP, leukocyte count), and radiographic checks were obtained every 6 months.

\section{Culture of tissue specimens}

Tissue specimens were homogenized in $3 \mathrm{ml}$ of brainheart-infusion broth for $1 \mathrm{~min}$ and the homogenate was inoculated in aliquots of $0.5 \mathrm{ml}$. Aerobic and aerobic sheep-blood agar were incubated at $35^{\circ} \mathrm{C}$ to $37^{\circ} \mathrm{C}$ in $5 \%$ 
Table 1 Clinical, microbiological, and laboratory data for the 21 patients with prosthetic joint infection

\begin{tabular}{|c|c|c|c|c|c|c|c|c|c|c|c|}
\hline $\begin{array}{l}\text { Patient } \\
\text { No/Age, } \\
\text { Y/Sex }\end{array}$ & Prosthesis & $\begin{array}{l}\text { Medical } \\
\text { condition }\end{array}$ & $\begin{array}{l}\text { Pre-operative } \\
\text { culture/ } \\
\text { Microorganism }\end{array}$ & $\begin{array}{l}\text { Pre-op } \\
\text { CRP mg/dl }\end{array}$ & $\begin{array}{l}\text { Intra- } \\
\text { operative } \\
\text { culture (i) }\end{array}$ & $\begin{array}{l}\text { Sonication } \\
\text { culture/ } \\
\text { Prosthesis }\end{array}$ & $\begin{array}{l}\text { Pre-2 }^{\text {nd }} \\
\text { stage CRP } \\
\text { mg/dl }\end{array}$ & $\begin{array}{l}\text { Interim Period/ } \\
\text { Second stage } \\
\text { surgery }\end{array}$ & $\begin{array}{l}\text { Intra- } \\
\text { operative } \\
\text { culture (ii) }\end{array}$ & $\begin{array}{l}\text { Sonication } \\
\text { culture/ } \\
\text { Spacer }\end{array}$ & $\begin{array}{l}3^{\text {rd }} \text { stage surgery/ } \\
\text { Follow-Up/Final } \\
\text { outcome }\end{array}$ \\
\hline 1/74/M & TKA & none & $\begin{array}{l}\text { joint aspiration } \\
\text { fluid/PA }\end{array}$ & 1.0 & no growth & no growth & 1.2 & $\begin{array}{l}30 \text { days/ } \\
\text { reimplantation }\end{array}$ & no growth & no growth & $\begin{array}{l}\text { none } / 28 \text { months/no } \\
\text { recurrence }\end{array}$ \\
\hline $2 / 65 / F$ & TKA & none & $\begin{array}{l}\text { joint aspiration } \\
\text { fluid/MSSA }\end{array}$ & 1.8 & MSSA & MSSA & 1.2 & $\begin{array}{l}30 \text { days/ } \\
\text { reimplantation }\end{array}$ & no growth & MSSA & $\begin{array}{c}\text { early debridement/ } \\
25 \text { months/no recurrence }\end{array}$ \\
\hline 3/70/M & TKA & none & $\begin{array}{l}\text { culture of sinus } \\
\text { tract/ PA }\end{array}$ & 2.5 & PA & PA & 2.1 & 85 days/arthrodesis & PA & PA & $\begin{array}{l}\text { none/23 months/no } \\
\text { recurrence/bony fusion }\end{array}$ \\
\hline 4/68/M & TKA & none & $\begin{array}{l}\text { joint aspiration } \\
\text { fluid/CONS }\end{array}$ & 2.8 & CONS & CONS & 0.4 & $\begin{array}{l}87 \text { days/ } \\
\text { reimplantation }\end{array}$ & no growth & no growth & $\begin{array}{l}\text { none/25 months/no } \\
\text { recurrence }\end{array}$ \\
\hline $5 / 71 / F$ & TKA & none & $\begin{array}{l}\text { joint aspiration } \\
\text { fluid/no growth }\end{array}$ & 2.3 & CONS & CONS & 0.3 & $\begin{array}{l}90 \text { days/ } \\
\text { reimplantation }\end{array}$ & no growth & no growth & $\begin{array}{l}\text { none/24 months/no } \\
\text { recurrence }\end{array}$ \\
\hline 6/70/M & TKA & none & $\begin{array}{l}\text { joint aspiration } \\
\text { fluid/no growth }\end{array}$ & 30.0 & CONS & CONS & 0.2 & $\begin{array}{c}90 \text { days/ } \\
\text { reimplantation }\end{array}$ & no growth & no growth & $\begin{array}{l}\text { none/28 months/no } \\
\text { recurrence }\end{array}$ \\
\hline 7/71/M & TKA & none & $\begin{array}{l}\text { joint aspiration } \\
\text { fluid/no growth }\end{array}$ & 3.1 & CONS & CONS & 0.3 & $\begin{array}{l}92 \text { days/ } \\
\text { reimplantation }\end{array}$ & no growth & no growth & $\begin{array}{l}\text { none } / 27 \text { months/no } \\
\text { recurrence }\end{array}$ \\
\hline $8 / 78 / \mathrm{M}$ & TKA & none & $\begin{array}{l}\text { culture of sinus } \\
\text { tract/ PA }\end{array}$ & 3.5 & PA & PA & 1.0 & 92 days/ arthrodesis & PA & PA & $\begin{array}{l}\text { none/25 months/no } \\
\text { recurrence/fibrous union }\end{array}$ \\
\hline 9/72/M & TKA & none & $\begin{array}{l}\text { joint aspiration } \\
\text { fluid/CONS }\end{array}$ & 4.1 & CONS & CONS & 0.4 & $\begin{array}{l}95 \text { days/ } \\
\text { reimplantation }\end{array}$ & no growth & no growth & $\begin{array}{l}\text { none/27 months/no } \\
\text { recurrence }\end{array}$ \\
\hline 10/55/F & THA & none & $\begin{array}{l}\text { joint aspiration } \\
\text { fluid/no growth }\end{array}$ & 3.5 & MSSA & MSSA & 0.3 & $\begin{array}{l}100 \text { days/ } \\
\text { reimplantation }\end{array}$ & no growth & MSSA & $\begin{array}{l}\text { early debridement/ } \\
20 \text { months/no recurrence }\end{array}$ \\
\hline $\begin{array}{c}11 / 64 / \\
M\end{array}$ & TKA & none & $\begin{array}{l}\text { joint aspiration } \\
\text { fluid/MSSA }\end{array}$ & 1.8 & MSSA & MSSA & 0.3 & $\begin{array}{l}120 \text { days/ } \\
\text { reimplantation }\end{array}$ & no growth & no growth & $\begin{array}{l}\text { none/26 months/no } \\
\text { recurrence }\end{array}$ \\
\hline $12 / 55 / F$ & TKA & diabetes & $\begin{array}{l}\text { joint aspiration } \\
\text { fluid/no growth }\end{array}$ & 0.3 & MSSA & CONS & 0.3 & $\begin{array}{l}120 \text { days/ } \\
\text { reimplantation }\end{array}$ & no growth & no growth & $\begin{array}{l}\text { none } / 27 \text { months/no } \\
\text { recurrence }\end{array}$ \\
\hline 13/62/F & THA & diabetes & none & 15.0 & CONS & CONS & 0.3 & $\begin{array}{l}125 \text { days/ } \\
\text { reimplantation }\end{array}$ & no growth & no growth & $\begin{array}{l}\text { none/23 months/no } \\
\text { recurrence }\end{array}$ \\
\hline $14 / 64 / F$ & TKA & none & $\begin{array}{l}\text { joint aspiration } \\
\text { fluid/no growth }\end{array}$ & 1.9 & no growth & no growth & 0.3 & $\begin{array}{l}150 \text { days/ } \\
\text { reimplantation }\end{array}$ & no growth & no growth & $\begin{array}{l}\text { none } / 23 \text { months/no } \\
\text { recurrence }\end{array}$ \\
\hline $\begin{array}{c}15 / 63 / \\
M\end{array}$ & TKA & none & $\begin{array}{l}\text { joint aspiration } \\
\text { fluid/MSSA }\end{array}$ & 2.0 & MSSA & none & 1.7 & $\begin{array}{c}150 \text { days/ } \\
\text { reimplantation }\end{array}$ & no growth & no growth & $\begin{array}{l}\text { none/26 months/no } \\
\text { recurrence }\end{array}$ \\
\hline $\begin{array}{c}16 / 68 / \\
M\end{array}$ & THA & psoriasis & $\begin{array}{l}\text { culture of sinus } \\
\text { tract/MRSA }\end{array}$ & 4.4 & MRSA & MRSA & 0.4 & $\begin{array}{l}180 \text { days/ } \\
\text { reimplantation }\end{array}$ & no growth & MRSA & $\begin{array}{l}\text { Girdlestone } \\
\text { arthroplasty } 18 \text { months/no } \\
\text { recurrence }\end{array}$ \\
\hline 17/58/F & TKA & schizophrenia & $\begin{array}{l}\text { culture of sinus } \\
\text { tract/ MSSA }\end{array}$ & 0.5 & CONS & MSSA & 0.7 & $\begin{array}{l}180 \text { days/ } \\
\text { arthrodesis }\end{array}$ & MSSA & MSSA & $\begin{array}{l}\text { none/24 months/no } \\
\text { recurrence/bony fusion }\end{array}$ \\
\hline 18/60/F & THA & none & $\begin{array}{l}\text { culture of sinus } \\
\text { tract/MSSA }\end{array}$ & 30.0 & MSSA & MSSA & 0.3 & $\begin{array}{l}180 \text { days/ } \\
\text { reimplantation }\end{array}$ & no growth & no growth & $\begin{array}{l}\text { none/26 months/no } \\
\text { recurrence }\end{array}$ \\
\hline
\end{tabular}


Table 1 Clinical, microbiological, and laboratory data for the $\mathbf{2 1}$ patients with prosthetic joint infection (Continued)

\begin{tabular}{|c|c|c|c|c|c|c|c|c|c|c|c|}
\hline $\begin{array}{c}19 / 66 / \\
M\end{array}$ & THA & none & none & 5.8 & CONS & CONS & 0.4 & $\begin{array}{l}180 \text { days/ } \\
\text { reimplantation }\end{array}$ & no growth & no growth & $\begin{array}{l}\text { none/22 months/no } \\
\text { recurrence }\end{array}$ \\
\hline 20/69/F & TKA & none & $\begin{array}{l}\text { joint aspiration } \\
\text { fluid/CONS }\end{array}$ & 2.0 & CONS & CONS & 0.5 & $\begin{array}{l}210 \text { days/ } \\
\text { reimplantation }\end{array}$ & no growth & no growth & $\begin{array}{c}\text { none } / 25 \text { months/no } \\
\text { recurrence }\end{array}$ \\
\hline $21 / 64 / F$ & TKA & none & $\begin{array}{l}\text { joint aspiration } \\
\text { fluid/no growth }\end{array}$ & 1.8 & no growth & no growth & 0.3 & $\begin{array}{c}240 \text { days/ } \\
\text { reimplantation }\end{array}$ & no growth & no growth & $\begin{array}{l}\text { none/29 months/no } \\
\text { recurrence }\end{array}$ \\
\hline
\end{tabular}

Abbreviations: CRP C-reactive protein, TKA total knee arthroplasty, THA total hip arthroplasty, MSSA methicillin-sensible Staphylococcus aureus, MRSA methicillin-resistant Staphylococcus aureus, CONS coagulase-negative Staphylococcus, PA Pseudomonas Aeruginosa. 
to $7 \%$ carbon dioxide aerobically and anaerobically for 5 days and 7 days, respectively.

\section{Sonication protocol}

The container was vortexed for 30 seconds using a VortexGenie (Scientific Industries, Inc, Bohemia, NY, USA) and then subjected to sonication (frequency $35-40 \mathrm{KHz}$ ) in an Aquasonic Model $750 \mathrm{~T}$ ultrasound bath (VWR Scientific Products, Radnor, PA, USA) for 5 minutes, followed by additional vortexing for 30 seconds. The resulting sonicate fluid was plated in $500 \mu \mathrm{l}$ aliquots onto aerobic Columbia sheep blood agar plates for 5 days and anaerobic Shaedler sheep blood agar for 7 days. Microorganisms were enumerated and classified by routine microbiological techniques. A total of $200 \mathrm{ml}$ of sonicate fluid was centrifuged at $2600 \mathrm{rpm}$ for 15 minutes and the sediment was gram stained. All bacteria were counted and identified by standard methods (VITEK Biomerieux, Bagno a Ripoli (FI), Italy).

\section{Statistical analysis}

Continuous variables are expressed as the median and interquartile range (IQR). Categorical variables were analyzed with a chi-squared test or Fisher's exact test. P $<0.05$ was considered statistically significant. SPSS software (SPSS Inc., Chicago, Illinois, USA) was used for the database and statistics.

\section{Results}

Table 1 presents the clinical and microbiological results of the patients who underwent a two-stage procedure to treat their PJI. The median length of the interim period between the two surgical stages was 120 days (IQR 90 to $180)$ and the median length of follow-up after last surgical procedure was 25 months (IQR 23 to 27). At the time of the second surgical stage, 18 patients underwent a reimplantation procedure and the remaining 3 patients received a knee arthrodesis. The sonication fluid culture of the removed spacer was positive in six cases (29\%) and the traditional culture of the periprosthetic tissue was positive in only three of these. In all cases with positive sonicate fluid culture of the removed spacer, the same pathogen that had caused the initial infection grew in the sonication culture of the cement spacer. In detail (Table 1), we detected three methicillin-sensible Staphylococcus aureus (MSSA), one methicillin-resistant Staphylococcus aureus (MRSA), and two Pseudomonas Aeruginosa infections. Two patients with MSSA infection (Table 1 - patients n. 2 and n. 10) of their spacer were successfully treated by aggressive debridement of the prosthetic joint within 30 days of prosthesis implantation and systemic antibiotic therapy tailored to the sensitivity of the cultures for 3 months. In three patients a knee arthrodesis was planned and performed as the second surgical stage. Two of them with highly resistant Pseudomonas Aeruginosa PJI (Table 1 - patients n. 3 and n. 8) did not respond to antibiotic therapy and presented wound dehiscence and opening of a sinus track. The third patient who received the knee arthrodesis was affected by MSSA infection (Table 1 - patient n. 17) and had been poorly compliant with the systemic antibiotic therapy due to her mental impairment. Both the traditional intraoperative culture at the time of the second surgical stage and the sonication culture of the cement spacer in these three patients were positive. The patient originally affected by MRSA infection of his primary total hip arthroplasty (THA)(Table 1 - patient n. 16) underwent removal of the infected prosthesis and a gentamicin and clindamycin-loaded cement spacer containing extra vancomycin was implanted. This patient firmly required to undergo implantation of a new THA at the second surgical stage and because of the complete normalization of clinical, laboratory, and nuclear medicine findings, a reimplantation was performed 180 days after the removal of the primary prosthesis. Unexpectedly, MRSA was isolated by the sonication culture of his cement spacer. This patient developed recurrent infection of his revision THA and eventually underwent Girdlestone arthroplasty.

\section{Discussion}

Two-stage exchange is the standard in the treatment of PJI. High frequency of success has been reported with this strategy of management, with a rate of eradication of both total knee arthroplasty [8] and THA [9] infection of more than 80 percent. Although not evaluated in randomized controlled trials, the application of a temporary antibiotic-loaded bone cement spacer in the interim period before revision surgery is largely used in the two-stage exchange protocol because it enables preservation of the joint space after removal of the primary joint arthroplasty and ensures high local concentrations of antibiotics that can help to eradicate the infection. Despite the adoption of the two-stage exchange protocol, there are cases of persisting PJI where the cement spacer itself may act as a biomaterial surface that facilitates survival of microorganisms $[3,10]$. Hence, it is of paramount importance to actively look for biofilm bacteria on the removed cement spacer to determine whether the infection has been cleared. Nevertheless, the limited sensitivity and specificity of standard microbiological culture techniques may limit their ability to detect the adherent bacteria responsible for PJI [11,12]. The application of ultrasound before culturing may disrupt the biofilm from the surface of orthopaedic implants and free the bacteria, enhancing the sensitivity of traditional cultures $[5,6]$. In the present study we used the sonication fluid culture of cement spacers to confirm 
the eradication of the infection obtained by a two-stage exchange protocol. We are aware of only one recent study that applied sonication culture to antibiotic-loaded spacers to identify bacterial growth on the cement spacer surface [13]. This study reported a $14.5 \%$ rate of positive sonication fluid cultures of the removed spacer and showed that an infection of the cement spacer is associated with poor clinical outcome. The sonicate fluid culture of the removed spacer in our study was positive in six cases $(29 \%)$. In three of these positive cases, the traditional culture of periprosthetic tissue failed to identify the pathogen. One notable difference with our results is that most sonication fluid cultures of the spacer in the above cited study were discordant with the culture of both the prosthesis (first-stage surgery) and periprosthetic tissue specimens (second-stage surgery). If a positive culture is obtained from the sonication process that reveals the same bacteria that caused the initial PJI as in the present study, it should be aggressively treated. The idea would be that in these cases a one stage exchange had been performed and a regimen of prolonged antibiotic therapy should be adopted.

Our results agree with the findings of other authors who reported MSSA and MRSA on gentamicin-and gentamicin-vancomycin-loaded cement beads, respectively, using traditional cultures [3,14]. For patients in whom pathogens are isolated on the cement spacer the outcome should be guarded, particularly when the infection is sustained by highly resistant microorganisms. Indeed, the patient with MRSA in this study developed a recurrent infection even though a cement spacer containing vancomycin had been used. The emergence of resistance in bacterial strains is a concern about the long-term exposure to antibiotics at the site of a previous infection [15]. In the case of MRSA infections, the prolonged implantation of gentamicin/vancomycinloaded spacers may be associated with bacterial survival, and hence with the persistence of infection [14], particularly when an insufficient debridement has been carried out at the time of explantation of the primary prosthesis. Other studies have reported high failure rates after twostage reimplantation when the infection is sustained by methicillin-resistant staphylococci [16-19]. In cases of PJI sustained by highly virulent microorganisms for which there is limited medical therapy, the arthrodesis or resection arthroplasty may be a viable option as the second stage surgery [20]. We performed a knee arthrodesis as the second surgical stage in three patients who either failed to respond or were poorly compliant to the antibiotic therapy. This proved to have been a fair therapeutic choice because of the culture of both the sonication fluid and the periprosthetic tissue on samples collected at the time of the second surgical stage which showed persistence of the infection in these three patients.
Some reservations must be stated with regard to the interpretation of our results. One doubt emerging from the present study is the practical usefulness of a diagnostic test on the cement spacer carried out after the reimplantation has already been performed. Even though one previous in vivo study showed bacterial biofilm adhesion to orthopaedic metals in the first 48 hours after implantation [21], the reinfection of the reimplanted prosthesis should be regarded and treated as an early infection with a retention strategy, because bacterial adhesion to the new implant and the biofilm formation have not yet been fully realized. Indeed, our results and those of previous studies [22-24] have demonstrated that patients with a short-term infection with a known pathogen and a stable implant may be successfully treated by early debridement, with retention of the prosthesis and the use of a standardized regimen of antimicrobial treatment. The major limitation of this study is the small sample size, which implies low statistical power. Moreover, although the mean duration of implantation of the cement spacer between the two surgical procedures in a two-stage protocol is highly variable in the literature, in our study it was long and it could be questioned that the long time that had elapsed between the two surgical stages may have affected the bactericidal power of the cement spacer and caused the growth of bacteria on its surface [1]. Actually, the ability of cement spacers to ensure long-lasting bactericidal levels of antibiotics is controversial. After one day, subinhibitory concentrations of antibiotics on Staphylococcus aureus strains from different cements have been detected in vitro [25] and a declining trend over time in the antibiotic release from cement spacers has been reported in vivo [26,27]. Conversely, other in vivo studies have shown that antibiotics released from the spacers result in long lasting bactericidal concentrations in the peri-prosthetic tissue [15,28]. Individual variations in the local perfusion, the different characteristics of the bone cement (porosity, roughness, total surface area), and the method and doses adopted to prepare the antibiotic-impregnated cement may lead to a variable in vivo concentration and bioactivity of the antibiotics released from the cement spacers and help to explain the discrepancy between the published data $[15,27]$. However, independent of the bactericidal power of the cement spacer, positive clinical results have been reported with long cycles of combined oral antibiotics plus a delayed reimplantation in the two-stage exchange protocol, even in infections sustained by highly resistant bacteria [29].

\section{Conclusions}

Bacteria may survive on antibiotic-loaded cement spacers, irrespective of the fact that they may have been 
preoperatively susceptible to the antibiotics included in the spacer. This might eventually result in a clinical reinfection. The sonication culture is a complementary method that can help to discover the possible persistence of microorganisms on an antibiotic-loaded cement spacer during a two-stage exchange protocol. Its use may help to confirm whether an infection has been definitely cleared, or whether further therapeutic options, such as the early debridment of the revision prosthesis, are necessary. Our results emphasize the importance of systemic antibiotics, given as a complement to the spacer implantation.

\section{Abbreviations}

PJl: Prosthetic joint infection; CRP: C-reactive protein; IQR: Interquartile range; MSSA: Methicillin-sensible Staphylococcus aureus; MRSA: Methicillin-resistant Staphylococcus aureus; THA: Total hip arthroplasty.

\section{Competing interest}

The authors declare that they have no competing interests.

\section{Authors' contribution}

MM: Conception and design, analysis of data, writing the manuscript, supervision. TA: Conception and design, analysis of data, critical revision of the manuscript. GB: Acquisition, analysis and interpretation of data, preparation of the manuscript. RR: Acquisition, analysis, and interpretation of data, critical revision of the manuscript. GGC and FS: Acquisition, analysis, and interpretation of data, preparation of the manuscript. MC Microbiological analysis, sonication, analysis of data. All authors read and approved the final manuscript.

\section{Author details}

'Department of Orthopaedic Surgery, "Federico II" University, Policlinico Federico II, Via S. Pansini 5, bd. 12, 80128, Naples, Italy. ${ }^{2}$ Department of Infectious Diseases, D. Cotugno Hospital, Naples, Italy. ${ }^{3}$ Department of Orthopaedic Surgery, C.T.O. Hospital, Naples, Italy. ${ }^{4}$ Laboratory of Microbiology, D. Cotugno Hospital, Naples, Italy.

Received: 19 March 2013 Accepted: 19 June 2013

Published: 24 June 2013

\section{References}

1. Sia IG, Berbari EF, Karchmer AW: Prosthetic joint infections. Infect Dis Clin North Am 2005, 19:885-914.

2. Huang MJ, Hsieh PH, Ueng SW, Ho KC, Yen TC, Lee MS: Use of positron emission tomography to detect infection around antibiotic-loaded cement spacers in patients with high c-reactive protein levels. Orthopedic 2011, 34(10):e605-e609.

3. Neut D, van de Belt H, Stokroos I, Van Horn JR, van der Mei HC, Busscher $\mathrm{HJ}$ : Biomaterial- associated infection of gentamicin-loaded PMMA beads in orthopaedic revision surgery. J Antimicrob Chemother 2001, 47(6):885-891.

4. Tunney MM, Patrick S, Gorman SP, Nixon JR, Anderson N, Davis Rl, Hanna D, Ramage G: Improved detection of infection in hip replacements. A currently underestimated problem. J Bone Joint Surg Br 1998, 80(4):568-572.

5. Trampuz A, Piper KE, Jacobson MJ, Hanssen AD, Unni KK, Osmon DR, Mandrekar JN, Cockerill FR, Steckelberg JM, Greenleaf JF, Patel R: Sonication of removed hip and knee prostheses for diagnosis of infection. N Engl J Med 2007, 357(7):654-663.

6. Holinka J, Bauer L, Hirschl AM, Graninger W, Windhager R, Presterl E: Sonication cultures of explanted components as an add-on test to routinely conducted microbiological diagnostics improve pathogen detection. J Orthop Res 2011, 29(4):617-622.

7. Berbari EF, Hanssen AD, Duffy MC, Steckelberg JM, Ilstrup DM, Harmsen WS, Osmon DR: Risk factors for prosthetic joint infection: case-control study. Clin Infect Dis 1998, 27(5):1247-1254
8. Jämsen E, Stogiannidis I, Malmivaara A, Pajamäki J, Poulakka T, Konttinen YT: Outcome of prosthesis exchange for infected knee arthroplasty: the effect of treatment approach. Acta Orthop 2009, 80(1):67-77.

9. Senthi S, Munro JT, Pitto RP: Infection in total hip replacement: metaanalysis. Int Orthop 2011, 35(2):253-260.

10. Cabo J, Euba G, Saborido A, González-Panisello M, Domínguez MA, Agulló JL, Murillo O, Verdaguer R, Ariza J: Clinical outcome and microbiological findings using antibiotic-loaded spacers in two-stage revision of prosthetic joint infections. J Infect 2011, 63(1):23-31.

11. Neut D, van der Mei HC, Bulstra SK, Busscher HJ: The role of small-colony variants in failure to diagnose and treat biofilm infections in orthopedics. Acta Orthop 2007, 78(3):299-308.

12. Schindler M, Christofilopoulos P, Wyssa B, Belaieff W, Garzoni C, Bernard L, Lew D, Hoffmeyer $P$, Uçkay I: Poor performance of microbiological sampling in the prediction of recurrent arthroplasty infection. Int Orthop 2011, 35(5):647-654.

13. Sorlí L, Puig L, Torres-Claramunt R, González A, Alier A, Knobel H, Salvadó M, Horcajada JP: The relationship between microbiology results in the second of a two-stage exchange procedure using cement spacers and the outcome after revision total joint replacement for infection: the use of sonication to aid bacteriological analysis. J Bone Joint Surg Br 2012, 94(2):249-253.

14. Anagnostakos K, Hitzler P, Pape D, Kohn D, Kelm J: Persistence of bacterial growth on antibiotic-loaded beads: is it actually a problem? Acta Orthop 2008, 79(2):302-307.

15. Hsieh PH, Chang YH, Chen SH, Ueng SW, Shih CH: High concentration and bioactivity of vancomycin and aztreonam eluted from simplex cement spacers in two-stage revision of infected hip implants: a study of 46 patients at an average follow-up of 107 days. J Orthop Res 2006, 24(8):1615-1621

16. Salgado CD, Dash S, Cantey JR, Marculescu CE: Higher risk of failure of methicillin-resistant Staphylococcus aureus prosthetic joint infections. Clin Orthop Relat Res 2007, 461(8):48-53.

17. Parvizi J, Azzam K, Ghanem E, Austin MS, Rothman RH: Periprosthetic infection due to resistant staphylococci. Clin Orthop Relat Res 2009, 467(7):1732-1739.

18. Leung F, Richards CJ, Garbuz DS, Masri BA, Duncan CP: Two-stage total hip arthroplasty: how often does it control methicillin-resistant infection? Clin Orthop Relat Res 2011, 469(4):1009-1015.

19. Mortazavi SM, Vegari D, Ho A, Zmistowski B, Parvizi J: Two-stage exchange arthroplasty for infected total knee arthroplasty: predictors of failure. Clin Orthop Relat Res 2011, 469(11):3049-3054.

20. Osmon DR, Berbari EF, Berendt AR, Lew D, Zimmerli W, Steckelberg JM, Rao N, Hanssen A, Wilson WR: Diagnosis and management of prosthetic joint infection: clinical practice guidelines by the infectious disease society of America. Clin Infect Dis 2013, 56(1):e1-e25.

21. Sheehan E, McKenna J, Mulhall KJ, Marks P, McCormack D: Adhesion of Staphylococcus to orthopaedic metals, an in vivo study. J Orthop Res 2004, 22(1):39-43.

22. Zimmerli W, Trampuz A, Ochsner PE: Prosthetic-joint infections. N Engl J Med 2004, 351(16):1645-1654

23. Trebse R, Pisot V, Trampuz A: Treatment of infected retained implants. J Bone Joint Surg Br 2005, 87(2):249-256.

24. Sukeik M, Patel S, Haddad FS: Aggressive early debridement for treatment of acutely infected cemented total hip arthroplasty. Clin Orthop Relat Res 2012, 470(11):3164-3170

25. van de Belt $H$, Neut D, Schenk W, Van Horn JR, van der Mei HC, Busscher $\mathrm{HJ}$ : Gentamicin release from polymethylmethacrylate bone cements and Staphylococcus aureus biofilm formation. Acta Orthop Scand 2000 71(6):625-629

26. Masri BA, Duncan CP, Beauchamp CP: Long-term elution of antibiotics from bone-cement: an in vivo study using the prosthesis of antibioticloaded acrylic cement (PROSTALAC) system. J Arthroplasty 1998, 13(3):331-338.

27. Anagnostakos K, Wilmes P, Schmitt E, Kelm J: Elution of gentamicin and vancomycin from polymethylmethacrylate beads and hip spacers in vivo. Acta Orthop 2009, 80(2):193-197. 
28. Fink B, Vogt $S$, Reinsch $M$, Büchner H: Sufficient release of antibiotic by a spacer 6 weeks after implantation in two-stage revision of infected hip prostheses. Clin Orthop Relat Res 2011, 469(11):3141-3147.

29. Cordero-Ampuero J, Esteban J, Garcia-Cimbrelo E: Oral antibiotics are effective for highly resistant hip arthroplasty infections. Clin Orthop Relat Res 2009, 467(9):2335-2342.

doi:10.1186/1471-2474-14-193

Cite this article as: Mariconda et al:: Sonication of antibiotic-loaded cement spacers in a two-stage revision protocol for infected joint arthroplasty. BMC Musculoskeletal Disorders 2013 14:193.

\section{Submit your next manuscript to BioMed Central and take full advantage of:}

- Convenient online submission

- Thorough peer review

- No space constraints or color figure charges

- Immediate publication on acceptance

- Inclusion in PubMed, CAS, Scopus and Google Scholar

- Research which is freely available for redistribution 